\title{
Comparative Cultivation Technique of Pleurotus Mushroom Grown on Different Biodegradable Substrates
}

\author{
Sadhana $\mathbf{B}^{1^{*}}$, Siva Kumar $\mathbf{M}^{2}$ \\ ${ }^{1}$ Centre for Research and P.G Department of Botany, Thiagarajar College, Madurai-625009, Tamil Nadu, India. \\ ${ }^{2}$ II M.Sc. Botany, Thiagarajar College, Madurai-625009. Tamil Nadu, India.
}

How to cite this paper: Sadhana B, Siva Kumar M. (2020) Comparative Cultivation Technique of Pleurotus Mushroom Grown on Different Biodegradable Substrates. International Journal of the Science of Food and Agriculture, 4(2), 109-128. DOI: $10.26855 /$ ijfsa.2020.06.002

Received: December 17, 2019

Accepted: January 15, 2020

Published: April 1,2020

*Corresponding author: Sadhana B, Centre for Research and P.G Department of Botany, Thiagarajar College, Madurai-625009, Tamil Nadu, India.

Email:

sadhanakarthik2004@yahoo.co.in

\begin{abstract}
Mushrooms are saprophytic fungal organisms grown on dead organic wastes derived from both plants and animals. They extracted the available nutrients from the different sources by decomposition process. Generally, edible mushrooms have high nutritive values like rich of proteins, vitamins and minerals, low level of carbohydrates and lipids. In the present study Oyster mushroom (Pleurotus ostreatus) were cultivated using various substrates news paper waste, coir waste. ground nut shell coat waste and paddy straw wastes under aseptic condition. The nutritional value of all the harvested mushroom basidiocarps from the various substrates have been analysed by determining the moisture, total ash (biomass), protein, fat, lipid and carbohydrates. Among this higher protein content was observed in both news paper wastes $\left(51.93^{\mathrm{b}} \pm 3.066 \%\right.$ and ground nut shell $\left(43.06^{\mathrm{ab}} \pm 6.025 \%\right)$ wastes based mushrooms. (Pleurotus ostreatus.) Thus edible mushrooms can be cultivated using biodegradable wastes from various sources. This commercial technology could be applied in small scale industry for production of Pleurotus mushrooms which was nutritionally efficient for our health at low cost.
\end{abstract}

Keywords

Edible Mushrooms, Pleurotus, Protein Rich Mushrooms and Basidiocarps

\section{Introduction}

Mushrooms are saprophytic fungal organisms which are fleshy, spore-bearing fruiting body, typically produced above ground on soil or on its food source such as dead and decay organic matter derived from plants and animals. Almost 3000 species of edible mushroom have been reported all over the world. Such edible mushrooms have a great nutritional value since they are quite rich in protein, with an important content of essential amino acids, vitamins, minerals, fiber and poor in fat and lipids.

Mushrooms are a kind of edible fungi belonging to the class: Basidiomycetes, subclass: Hollo basidiomycetidae, order:Agaricales. Pleurotus is the second most cultivated edible mushroom worldwide after Agaricus bisporus which constitute about $25 \%$ of total world production of cultivated mushrooms. Pleurotus species are commonly called "Oyster mushrooms" which are having specific flavor and taste when prepared as food stuffs. Mushrooms represent one of the world's greatest untapped resources of nutritious food. Cultivation of edible mushrooms may be the only currently economical biotechnology for lingo cellulose organic waste recycling that combines the 
production of protein rich food with the reduction of environmental pollution [1].

Pleurotus mushrooms are helpful in human ailments because they possess many typical pharmacological features like: to act as metabolic activators, prevent intoxication and microbial infections, help in immune-balancing and as antioxidants with rejuvenating and energy boosting properties. The cultivation and analysis of nutritional value of Pleurotus sajor-caju on a relatively large scale using cotton waste as substrate and they obtained such mushroom had higher protein content than and comparable carbohydrate content to Agaricus bisporus, Volvarielta volvacea, Lentinus edodes and Pleurotus ostreatus sand low content of the crude fats, ash, energy value, vitamin and mineral contents. The biological efficiency from cotton waste compost was lower than that from straw compost [2].

Mushrooms not only convert ligno cellulosic waste materials into human food, but also can produce notable nutriceutical products, which have many health benefits. They provided people with an additional vegetable of high quality and enrich the diet with high quality proteins, minerals and vitamins which can be of direct benefit to the human health and fitness. Edible mushrooms are highly nutritious and can be compared with eggs, milk and meat. The extractable bio-active compounds from medicinal mushrooms would enhance human's immune systems and improve their quality of life. The content of essential amino acids in mushroom is high and close to the need of the human body. It is also easily digestible and it has no cholesterol content [3].

Pleurotus species grown on the parts of plants which was generally poor in nutrients and vitamins. Sufficient waste materials derived from vegetable wastes and food industry including lignin and cellulose materials such as corn cobs, all cereal straws, paper, wood shavings, sawdust, nutshells were responsible for spawn running and fruit body development [[4] \&[5]] of the fungi. Pleurotus species have extensive enzyme systems capable of utilizing complex organic compounds which were derived from agricultural wastes and industrial by-products. This would lead to avoid processing of substrates for cultivation of Pleurotusspecies [[6] \& [7]].

Malnutrition is a problem in developing third world countries. Mushrooms with their flavour, texture, nutritional value and high productivity per unit area have been identified as an excellent food source to alleviate malnutrition in developing countries [8]. They are consumed as meat substitutes and gives flavouring to the food. Edible mushrooms are low in fat and calories, rich in vitamin B and C, contain more protein than any other food of plant origin and are also a good source of mineral nutrients [9].

Oyster mushrooms can help to reduce vulnerability to poverty and strengthen livelihoods through the generation of a fast yielding and nutritious source of food and a reliable source of income. The edible mushrooms have several advantages includes: high production per small surface area, healthy food over many other crops, like nutritional value (vitamins, proteins, minerals, fat and carbohydrates) and medicinal values [[3] \& [10]].

Edible mushrooms are a good source of non-starchy carbohydrates with high content of dietary fiber and moderate quantity of proteins, including most amino acids, minerals and vitamins. The protein content varied from 1.6 to $2.5 \%$, and the niacin content is about ten times higher than that of any other vegetable. Researcher who [11] reported that oyster mushrooms are rich in Vitamin C, B complex, and mineral salts required by the human body. It is important to select high-yielding strains for successful cultivation. However, the production and yield performance of commercial strains of mushrooms tend to decrease after consecutive sub culturing [12].

Oyster mushroom can grow at moderate temperature ranging from $20^{\circ}$ to $300^{\circ} \mathrm{C}$ and humidity $55-70 \%$ for a period of 6 to 8 months in a year. It can also be cultivated in summer months by providing the extra humidity required for its growth in hilly areas above $900 \mathrm{~m}$. (m.s.l.), the best growing season is during March/April to September/October and in the lower regions from September/October to March/April. The cultivation of Pleurotus spp. has been tested indifferent bagging systems like trays, cylindrical containers, wooden or polystyrene racks, blocks and plastic bags [13]. Cultivation in plastic bags was reported to yield more harvest than other types with less contamination level [14].

Commercially, mushroom cultivation is the classical example of solid state fermentation method in biotechnology and has more advantages like low grade substrate-ligno cellulosic waste recycling and with high productivity using lingo cellulosic substrate approximately reducing environmental pollution. It is established that such cultivated mushroom contains reasonable amounts of nutrition between low grade vegetables and high grade meats. They are considering as a "vegetarian meat" in our food stuffs. Here an attempt was made to study the cultivation technique of Pleurotus mushroom using different biodegradable substrate and analyze them comparatively. 
The preliminary study was initiated by cultivation of oyster mushroom the lab condition with the following objectives:

- Sampling

- Preparation of pure culture

- Preparation of spawn

- Preparation of substrate

- Inoculation

- Incubation

- Harvesting

The secondary study was analyzed with following objectives:

* To study the biochemical characteristics and nutritive component analysis of oyster mushroom.

- Determination of Moisture.

- Determination of Ash content.

- Determination of Protein.

- Determination of Fat.

- Determination of Lipid.

Determination of carbohydrate.

\section{Methodology of Mushroom Production Technique}

\section{Agro-climatic Requirements}

Oyster mushroom was grown at moderate temperature ranging from $21^{\circ} \mathrm{C}$ to $30^{\circ} \mathrm{C}$ and humidity $55-70 \%$ for a period of 2 to 6 months in a year. It was cultivated in winter season.

\section{Variety Cultivated}

Among all the cultivated mushrooms Genus: Pleurotus has maximum number of commercially cultivated species suitable for commercial cultivation. The Pleurotus ostreatus was selected for the cultivation purpose and utilized for further analysis.

\section{Sampling}

The spawn culture of oyster mushroom (mushroom seed) was collected from the Tamil Nadu Agricultural University, Madurai. It was a source of inoculum for further cultural methods.

\section{Mushroom Cultivation Techniques}

$>$ Pure culture of Oyster mushroom

$>$ Preparation of spawn

$>$ Preparation of substrate for commercial cultivation

$>$ Spawn inoculation

$>$ Incubation

$>$ Harvesting and storage

\section{a) Pure culture method of Oyster mushroom}

The potato dextrose agar medium was prepared and sterilized in a autoclave at $121^{\circ} \mathrm{C}, 15 \mathrm{lb}$ pressure for $15-20$ minutes. The medium was poured into a sterilized petriplates. After solidification, a small piece of inoculam of mycelium from spawn bottle was inoculated on a plate. The inoculated plates were incubated at room temperature for 2-4 days .

The composition for PDA medium

$\begin{array}{llr}>\text { Potato } & - & 200 \mathrm{~g} . \\ >\text { Dextrose } & - & 18 \mathrm{~g} . \\ >\text { Agar } & - & 20 \mathrm{~g} . \\ >\text { Water } & - & 1000 \mathrm{ml} .\end{array}$

The well grown culture was sub cultured frequently for maintaining the viability of mycelium. They were used for further study (Plate : 1). 


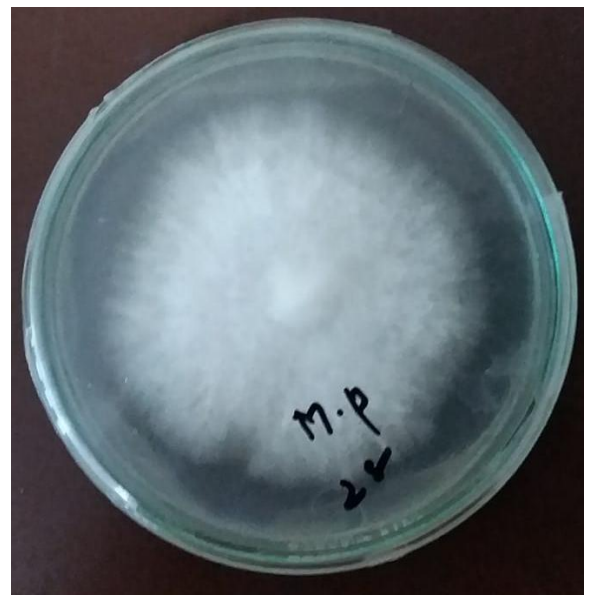

(a)

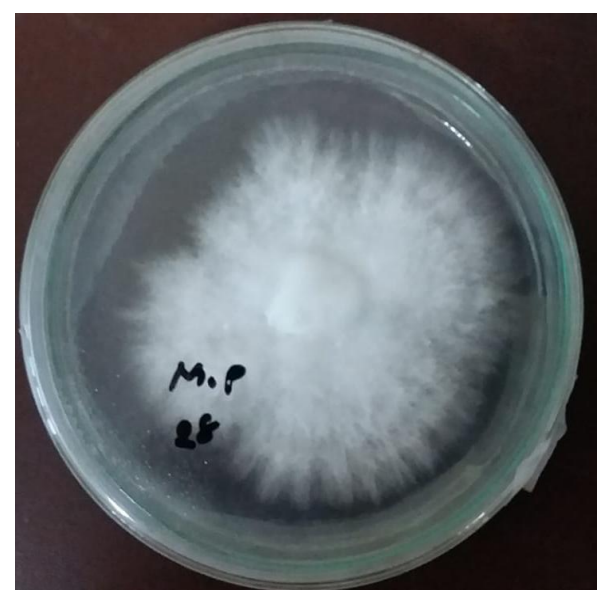

(b)

Plate: 1 Pure culture of Oyster mushroom under laboratory condition (a \&b)

\section{b) Preparation of Spawn}

A pure culture of oyster mushroom was inoculated on the different sterilized substrates such as Paddy straw, Sorghum, maize and wheat grains. These inoculated substrate bottles were incubated at room temperature for 2 to 3 weeks.

\section{Method}

Three hundred gramof the selected substrate (Paddy straw,Sorghum,maize, wheat grains were purchased from Departmental store, Tepakkulam, Madurai)was soaked in sterile water for 3-5 hrs. After soaking, the substrate was drained off and it was mixed with a 3-4 grams of (8\%) calcium carbonate for the absorption of water and moisture. Then they were transferred into glass bottles. Only three fourth of the glass bottle was filled with substrate. Such bottles were sterilized in autoclave at $121^{\circ} \mathrm{C}, 15 \mathrm{lb}$ pressure for $15-20$ minutes. After cooling, they were inoculated the pure culture of mycelium and shaken thoroughly for the proper growth of mycelium spread over the substrate. The inoculated bottles were incubated at $24^{\circ} \mathrm{C}$ to $33^{\circ} \mathrm{C}$ for $7-14$ days. After incubation, the inoculated bottles were observed for mass colonization of oyster mushroom mycelium. It was used as a source of inoculum for further commercial cultivation ( Plate : 2 ).

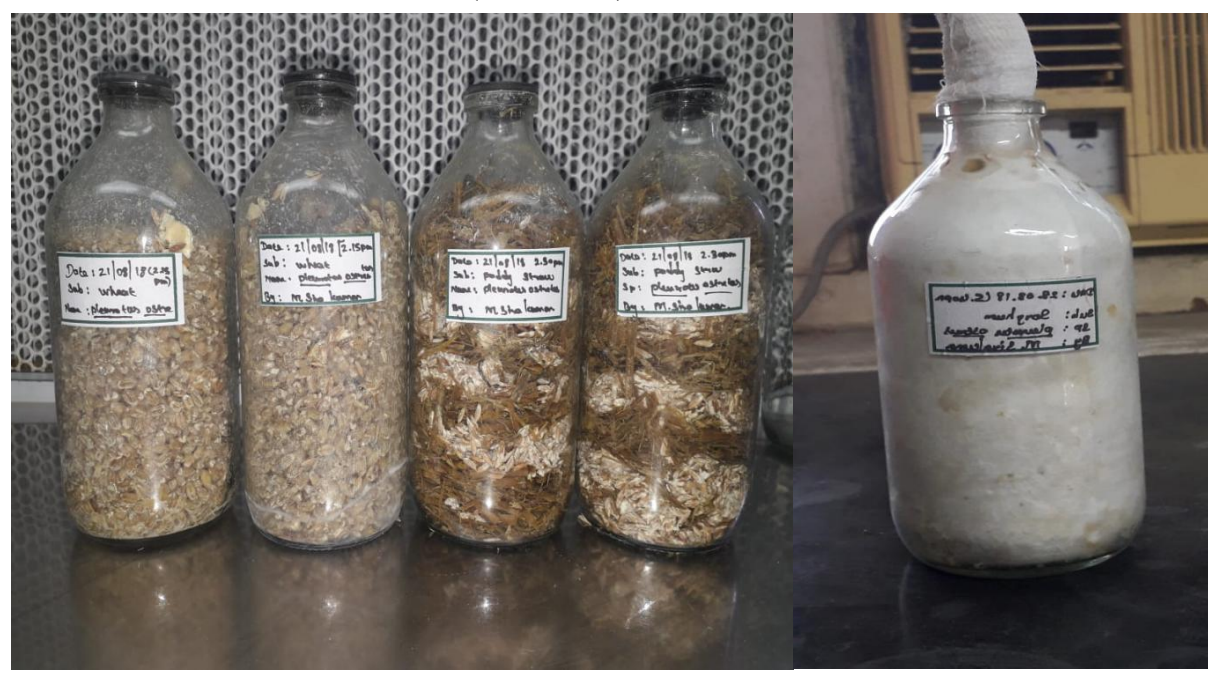

Plate: 2 Preparation of spawn for commercial cultivation

\section{c) Preparation of substrate for commercial cultivation}

Four different cellulosic substrates namely news paper waste, coir waste, ground nut shell and paddy straw 
were selected for commercial cultivation of oyster mushroom under aseptic condition. These substrates were sterilized in an autoclave at $121^{\circ} \mathrm{C}, 15 \mathrm{lb}$ pressure for $15-20$ minutes. After the sterilization, these substrates were drained off and dehydrated with mixing of Calcium carbonate $(8 \%)$ for absorption of moisture and water in the substrate.

\section{d) Spawn inoculation}

The sterilized substrates of different sources were packed into a polythene bag (size $40 \mathrm{~cm}$ length x $15 \mathrm{~cm}$ breath) in compact layer alternatively (one layer which was followed by spawning done in right angles with a crisscross pattern) inoculated with spawn culture. This process was repeated for 3 to 6 layers, it depends upon the bag size and the final layer was packed with loose substrate. Inoculated bags were tied on the top with thick thread and leaving a space above the bag for aeration. And it was incubated in incubator. These bags were perforated with needles for maintaining proper aeration to initiate the mycelia grown in a substrate (Plate : 3 ).

\section{e) Incubation}

The spawned bags were kept for incubation at $21^{\circ} \mathrm{C}$ to $30^{\circ} \mathrm{C}$ and with a sufficient light and ventilation for $15-17$ days for spawn growth and mycelium development. In this place the bags were hanged below the bamboo basket with thick threads and it was covered with wet cloth. Water was sprayed over the bags twice a day to maintain the moisture (Plate : 5 ).

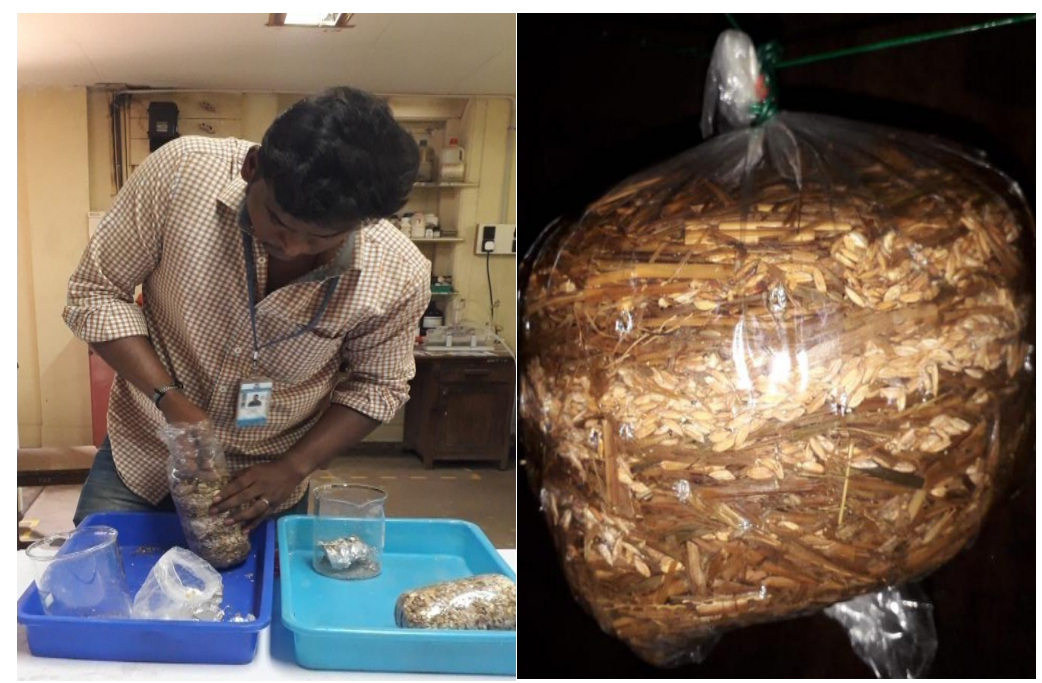

Plate:3 Method of Mushroom substrate bag preparation and spawn inoculation

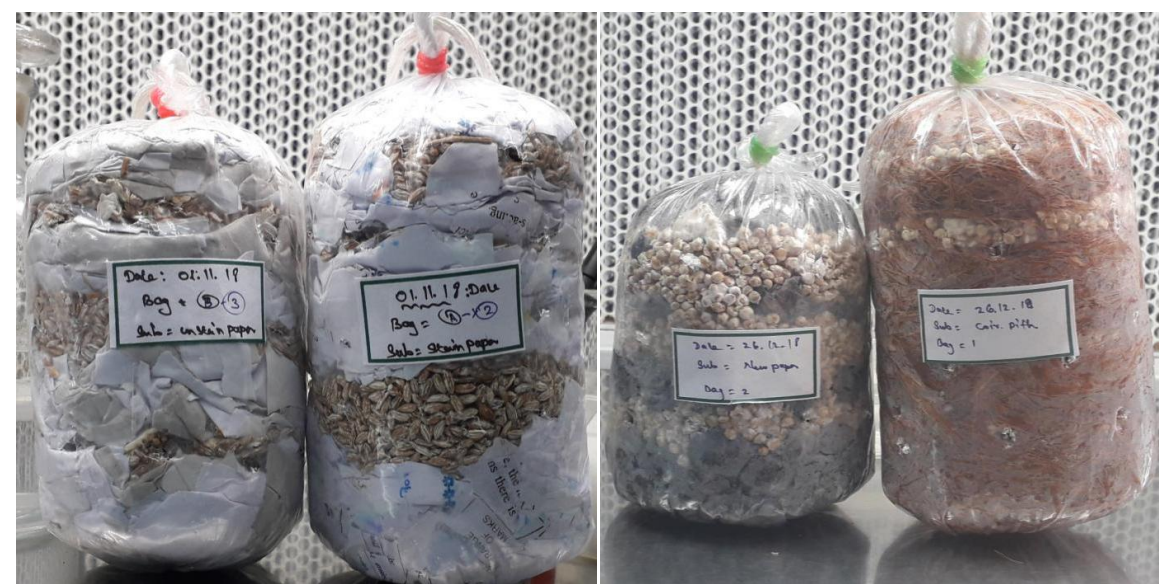

Plate: 4 Substrate bag inoculation and packed for incubation 


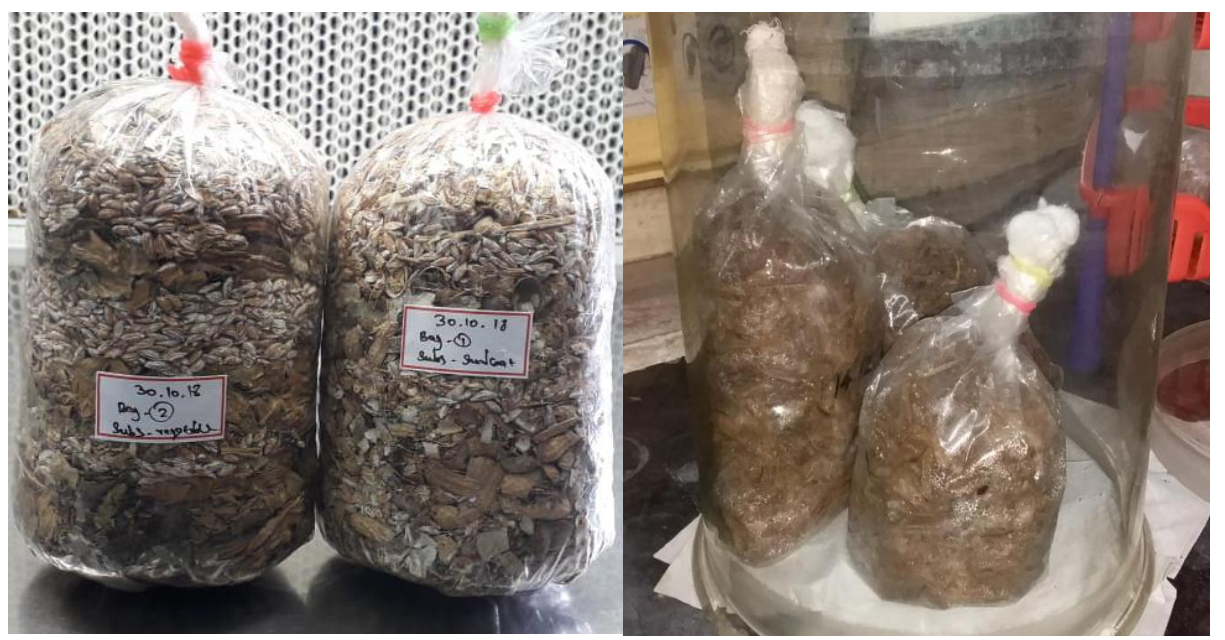

Plate: 5 Spawn inoculated substrate bags incubated under aseptic condition

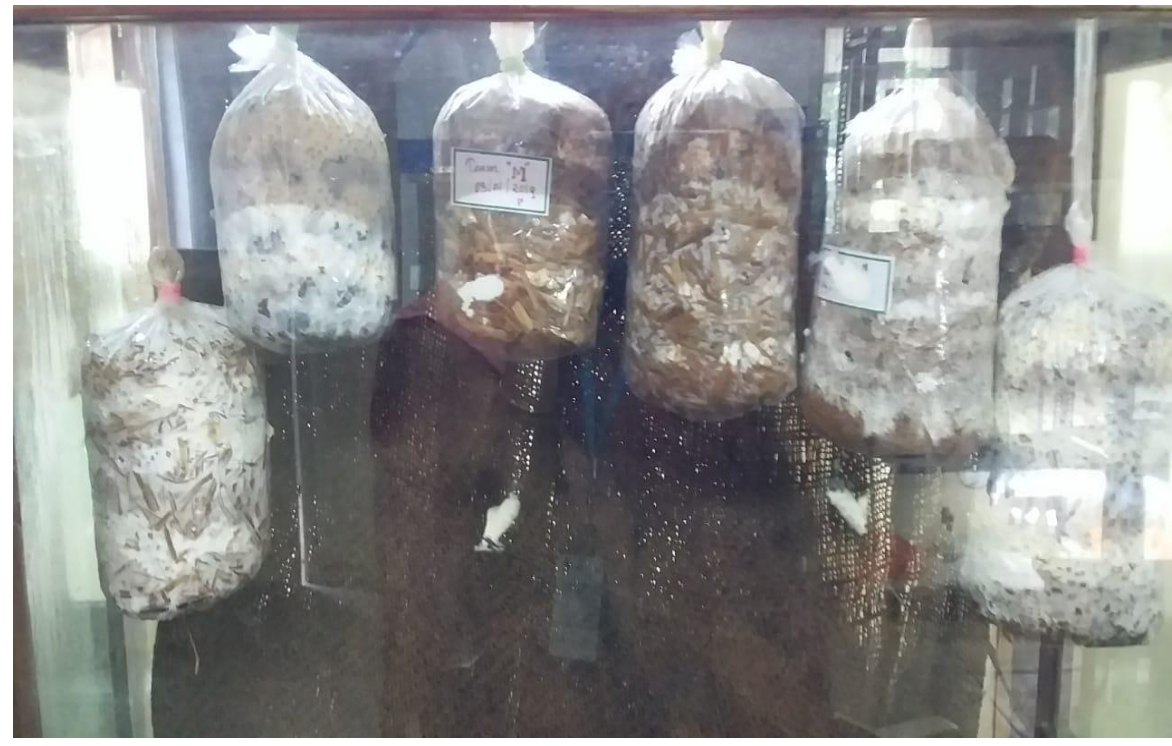

Plate: 6 Spawn running process after 2-3 weeks of inoculation

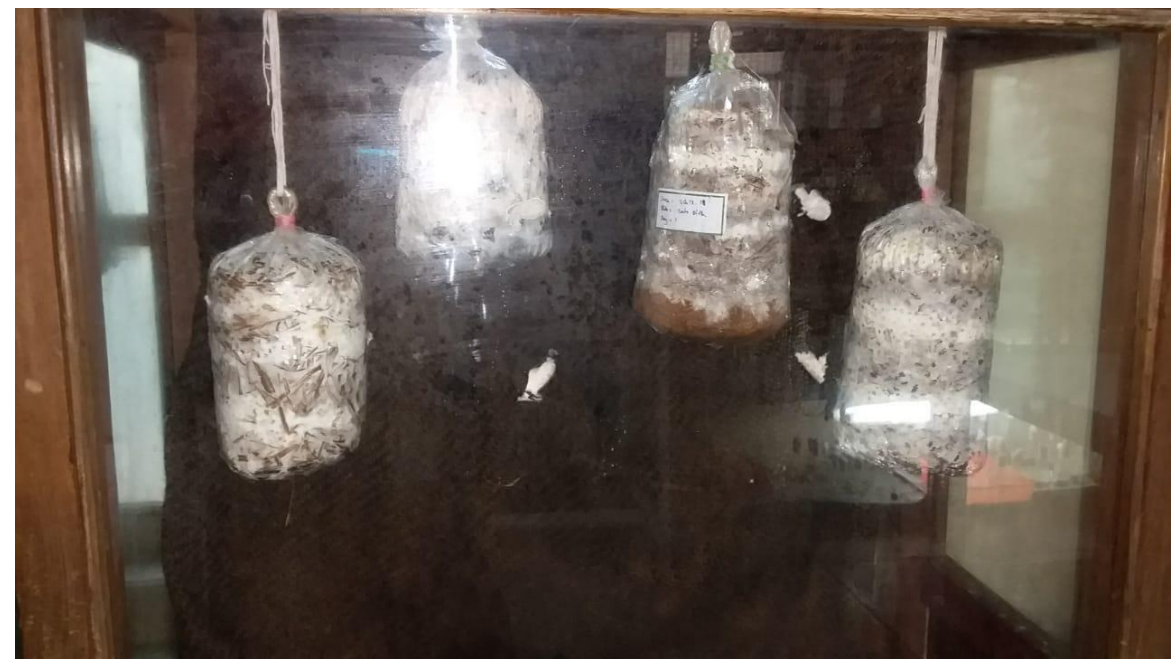

Plate: 7 Spawn running in all substrate bags 


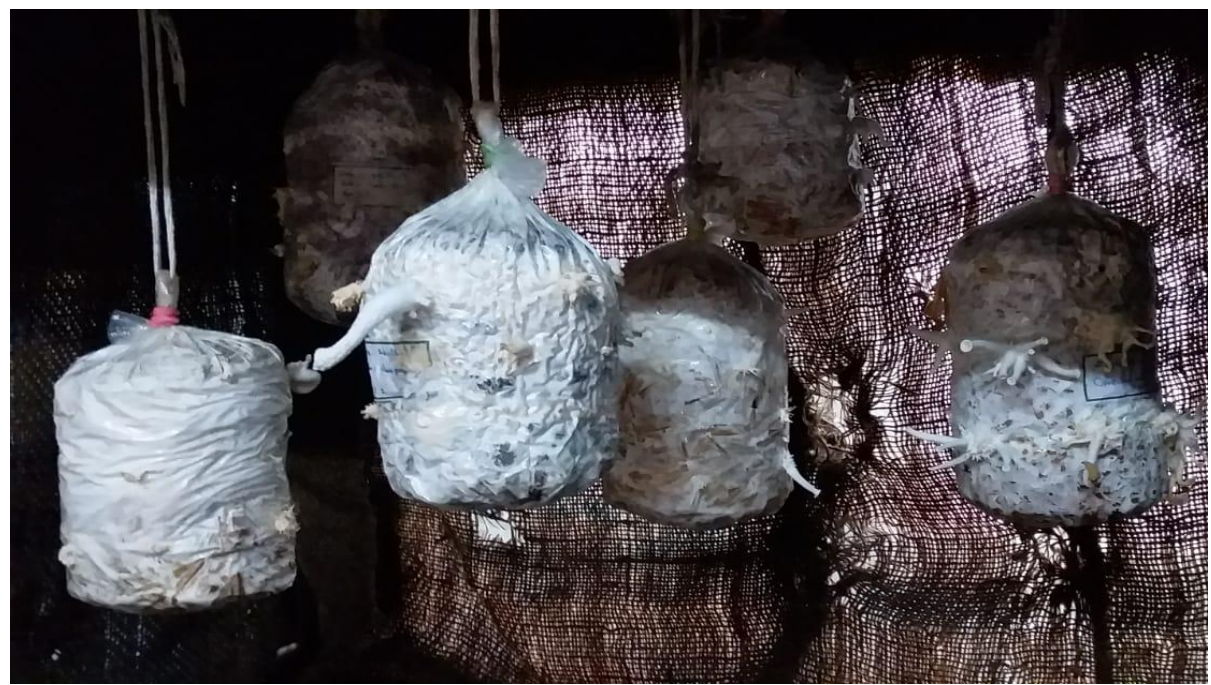

Plate: 8 Mushroom Pin head formation in all substrate bags after 2-3 weeks

\section{$\checkmark \quad$ Fruiting}

The mycelium was fully colonized on the substrate and the fungus was ready for fruiting. All the bags required high humidity (70-85\%) during fruiting. The water was frequently sprayed over the bags in the cropping place depending upon the atmospheric humidity. Sufficient ventilation was provided during fruiting( Plate : 9).
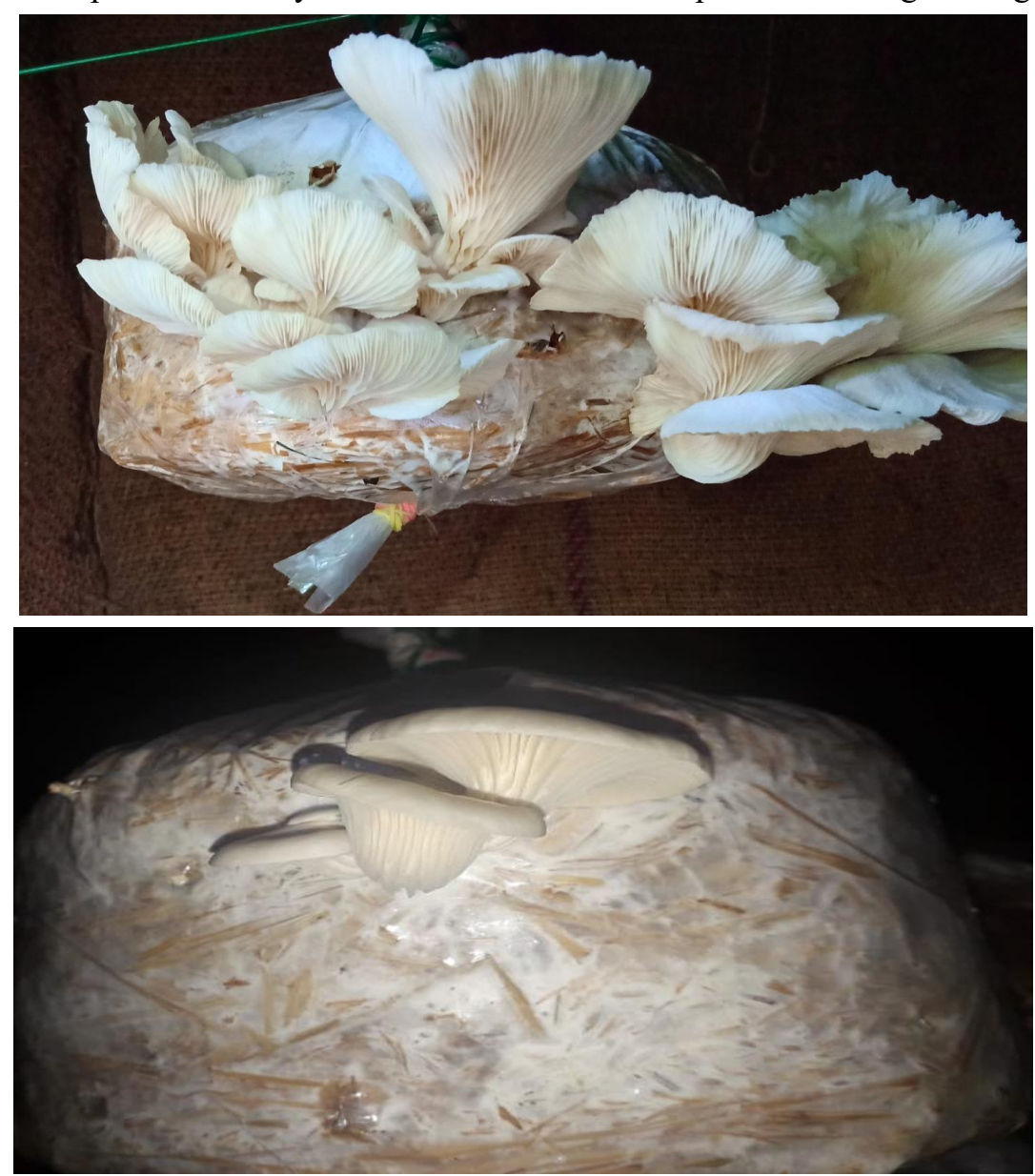

Plate: 9 Sprouting of Oyster mushroom fruiting body in paddy straw substrate bag 

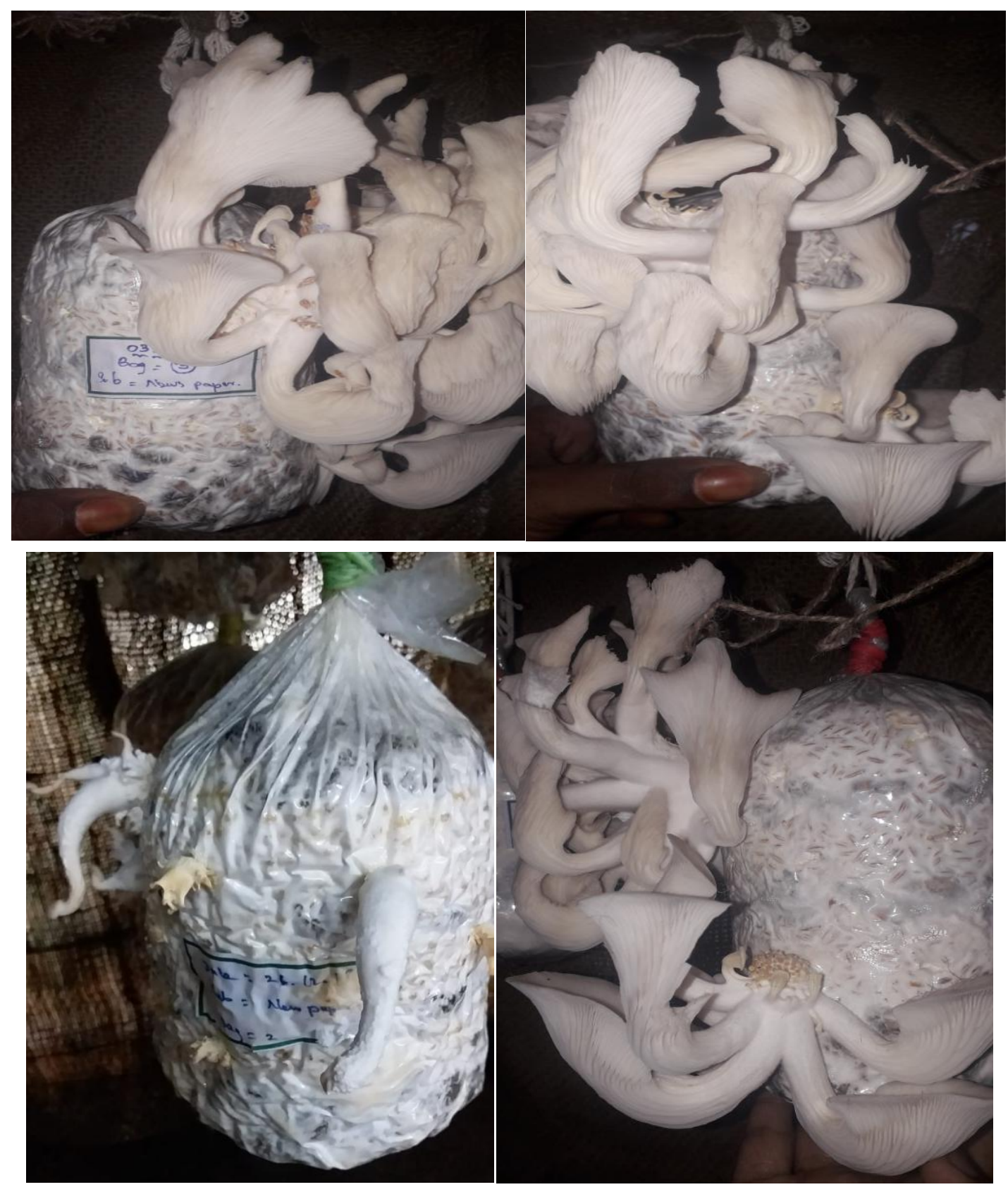

Plate: 10 Florished fruiting body of Oyster mushroom in paper substrate and ground nut shell substrate bag

\section{$\checkmark \quad$ Crop protection}

The crop was protected from flies, mites and other diseases by proper monitoring and pruning.

\section{f) Harvesting and storage}

The right time for crop harvesting was done based on the shape and size of the fruit body by hand picking. The fruiting bodies were harvested before spore release by twisting. They were harvested for three times/bag from every 12-16 days of incubation. The harvested mushroom fruiting bodies were measured per bag of substrate using electronic balance (Plate : $11 \& 12$ ).

\section{$\checkmark$ Short - term storage}

Fresh mushrooms were packed in perforated polythene bags and it was stored at low temperature $\left(0-5^{\circ}\right)$ for $1-2$ weeks without lose in quality. These mushroom samples were collected and studied for further analysis. 


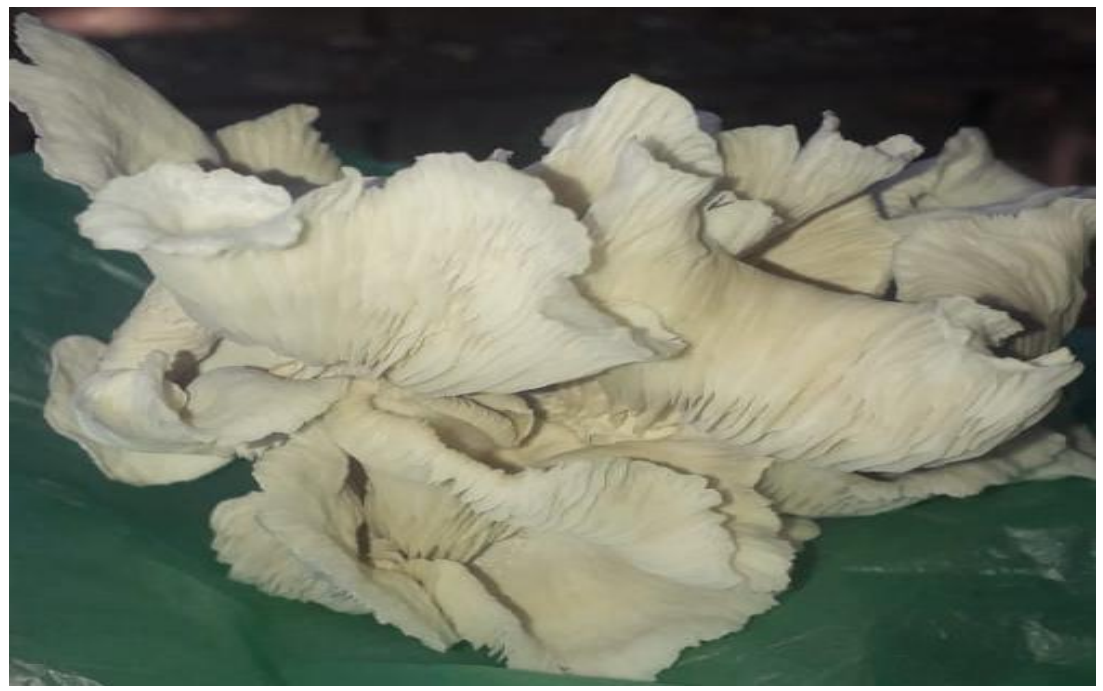

Plate: 11 Harvested Oyster mushrooms

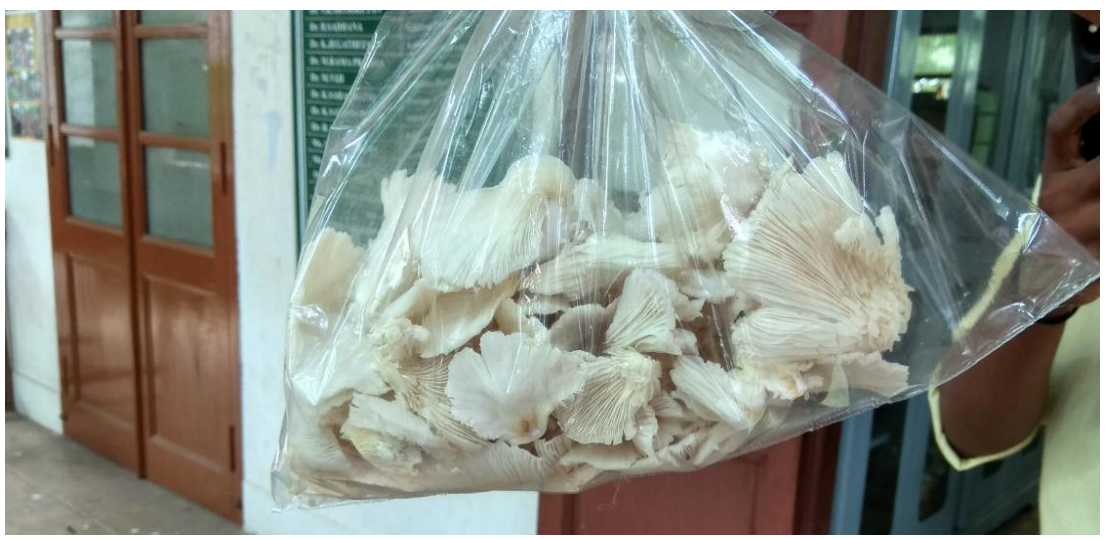

Plate:12 Packing of harvested mushrooms

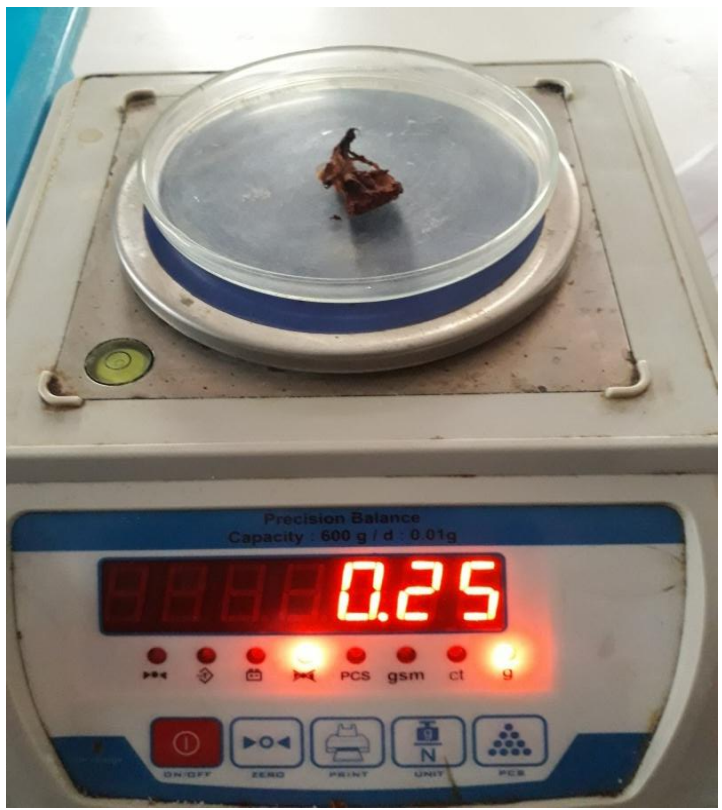

Plate: 13 Determination of total ash content 


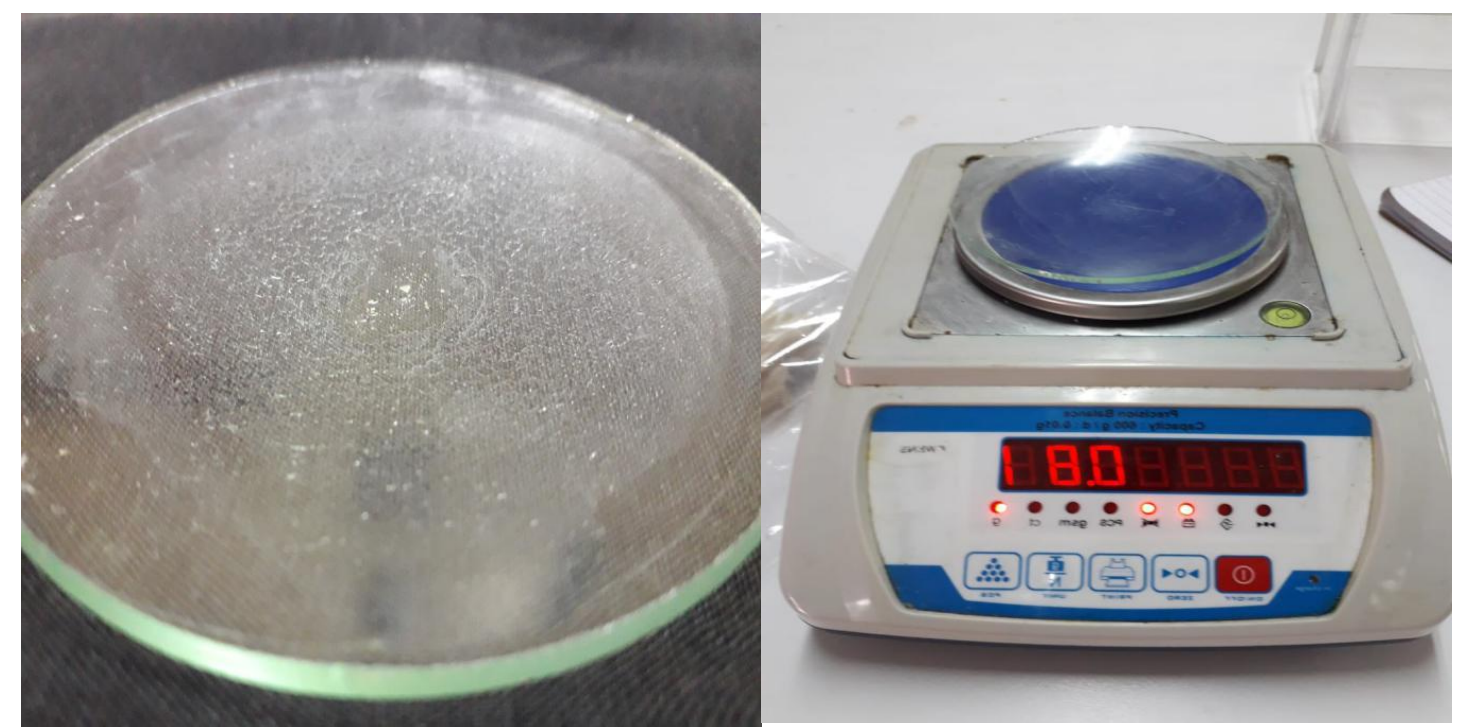

Plate:14 Determination of Total Fat content

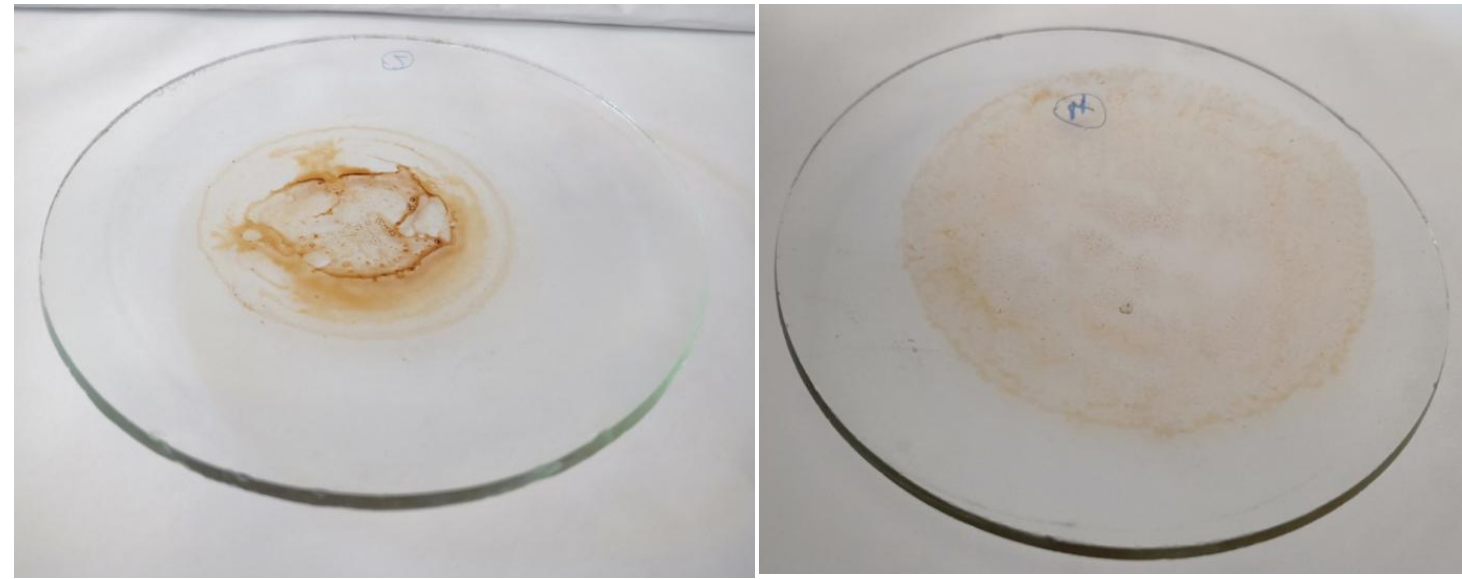

Plate:15 Determination of Total Lipid

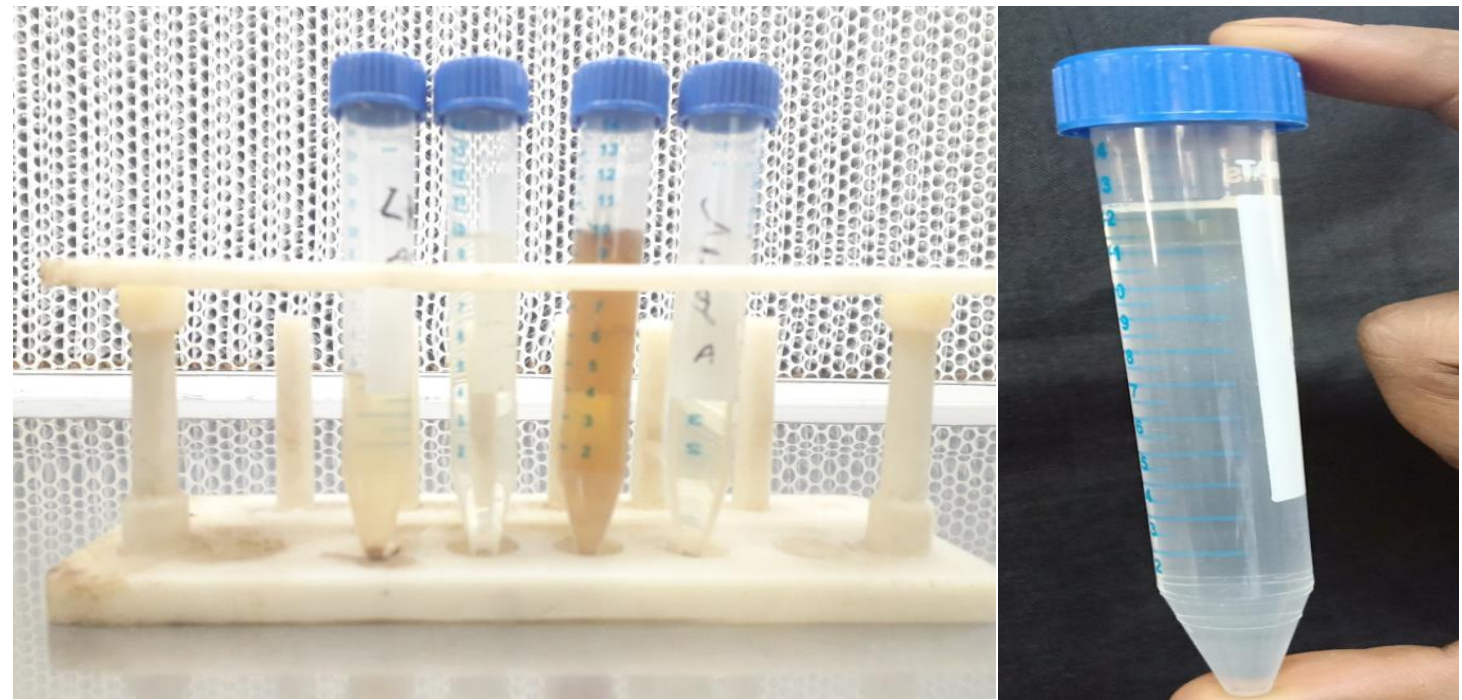

Plate:16 Determination of Total Protein (Bradford Method) 


\section{Secondary study}

\section{Determination of Moisture [15]}

The moisture content was determined by measuring the sample weight before and after the water content was removed by evaporation.

Percentage of moisture $=($ Initial fresh weight- final weight $) \times 100$ lweight of sample.

\section{Determination of Total Ash content [16]}

About three grams of mushroom sample was weight in a electronic balance and heated in a hot air oven at $170^{\circ} \mathrm{C}$ for $30 \mathrm{~min}$ and cooled. The ash content was calculated using the following formula:

Ash content $(\mathrm{g} / 100 \mathrm{~g}$ sample $)=$ Weight of ash/weight of sample taken $\mathrm{x} 100$

\section{Determination of Total Fat content [16]}

About ten grams of mushroom sample was weighed and extracted with petroleum ether in an extraction apparatus for 16 hours. The extract was dried, cooled and weighed. This was recorded and the percentage of fat was determined using the following fornula:

Percentage of fat $=100$ (Weight of Soxhlet flask with extract fat - Weight of empty Soxhlet flask)/Weight of sample

\section{Determination of Total Lipid [17]}

Five grams of mushroom sample was suspended in $50 \mathrm{ml}$ of chloroform: methanol (2:1)mixture then mixed thoroughly and let stand for 3 days. The solution was filtrated and centrifuged at $3000 \mathrm{rpm}$ by a centrifuge. The upper layer of methanol was removed by pipette and chloroform was made to evaporate by keeping it in hot air oven. The remaining was measured as crude lipid.

\section{Determination of Total Protein [18]}

About $2 \mathrm{~g}$ of mushroom samples were cut into pieces with a scissor and grind in mortar with $5 \mathrm{ml}$ of phosphate buffer ( $\mathrm{pH}$ 7.6) and was then transferred to the centrifuge tubes. The homogenate was centrifuged at $8000 \mathrm{rpm}$ for 20 minutes. The supernatant of different mushroom sample were collected in separate tubes. The volume of all samples in tubes was then made equal by adding phosphate buffer solution and extracts were stored in the refrigerator at $4^{\circ} \mathrm{C}$. A drop of comasive brilliant blue (G-250) was added in each sample. The absorbance of the solution was measured at $620 \mathrm{~nm}$ by using UV-Visible Spectrophotometer-SPECTRONICS-109. The bovine serum albumin was used as standard for further calculation.

\section{Determination of Carbohydrates}

The content of the available carbohydrate was determined by the following formula. The percentage of carbohydrate $=(100$-total protein + total ash + total fat $)$.

\section{Statistical Analysis}

The data collected in this study was subjected to analysis of variance (ANOVA). and means descriptive statistics.

\section{Result and Discussion}

Mushrooms are the fruit bodies of macroscopic filamentous and epigeal fungi made up of hyphae which interwoven web of tissue known as mycelium in the substrate upon which the fungus feeds; most often their mycelia are buried in the soil around the roots of trees, beneath leaf litters in the tissue of a tree trunk or in other nourishing substrate. Mushroom contains protein on dry weight basis, which can play a constructive role in solving one of the main problems in the twenteeth century, the need to feed an increasing population. Edible mushrooms have different nutrients such as protein, carbohydrates, lipids, vitamins and minerals. It has been produced and consumed for all centuries.

Oyster mushroom production technology under controlled conditions has been extensively developed, especially via the recycling of agricultural waste. It has been widely accepted in rural systems mainly due to its simple and cheap procedure requirement [19]. Cultivation of edible mushrooms might be the only current process that combines the production of protein-rich food with the reduction of environmental pollution [20]. It represented one of the most efficient biotechnological processes for lingo-cellulosic organic waste 
recycling [21].Oyster mushroom has been widely cultivated in many different parts of the world. It has abilities to grow at a wide range of temperatures utilizing various lignocelluloses [20]. A high content of protein and nitrogen source has been reported to be effective in shortening the growth period and increasing both the yield and biological efficiency [22].

Generally, mushroom cultivation technology is very vital in the tackle against shortage of food, diminishing quality of human health and pollution of the environment, which human beings still face and will continue to face, due to the continued increase of the world population, natural resource degradation and impacts from climate change [23].

In the present study the preliminary investigation started with the collection of pure culture of mushroom spawn from Tamil Nadu Agricultural College, Madurai and was subculturing under aseptic condition in microbiology laboratory. Then the same culture was subculturing continuously. The spawn mycelium of Pleurotus ostreatus was prepared using different substrates Paddy straw, Sorghum, Maize and Wheat grains. Maximum mycelial growth was observed vigorously on all substrates. The selective grain spawn was used for the mushroom bag preparation work (Plate: 1-7).

In the present study all the spawn inoculated substrates (News paper, Coir, Groundnut shell and Paddy straw) showed mass growth of mycelium within 11- 18 days. But the pin head formation occurs in various time interval viz. news paper waste substrate in 11 days, coir waste substrate in 16 days, ground nut shell coat waste in 19 days and paddy straw substrate in 13 days (Plate: 8 ). The favourable climatic condition determined the fruiting body formation in selective substrates. But the fruiting body was sporuted from news paper substrate bag on $17^{\text {th }}$ day period, in coir waste substrate on $26^{\text {th }}$ day, in ground nut shell coat waste on $25^{\text {th }}$ day and paddy straw substrate on $19^{\text {th }}$ day (Plate : 9). Such result indicated that mycelium colonization, pin head formation and fruiting body development in all biodegradable substrates depends on the physical environment which might be optimum for the selective edible mushroom Pleurotus ostreatus. According to the investigator [24] mushroom mycelia require specific nutrients for its growth; the addition of supplements can, thus, increase mushroom yield through the provision of these specific nutrients. Pin-head formation (premordium initiation) was observed following the invasion of substrates by mycelia growth. The time required for the formation of pinhead is comparable with other similar studies elsewhere.

Such variations in mycelia growth rate, colonization and primordial initiation have been observed when a mushroom species were grown on a range of substrates including sawdust, bagasse, and banana leaves [25].

Oyster mushroom species (Pleurotus columbinus, P. sajor-caju and P. ostreatus) are cultivated using various lingo cellulosic wastes as substrates (untreated organic wastes including chopped office papers, cardboard, sawdust and plant fibres). The highest biological efficiency was noted with P. columbinus on cardboard (134.5\%) and paper $(100.8 \%)$, whereas $P$. ostreatus produced maximum yield on cardboard $(117.5 \%)$ followed by paper (112.4\%). The overall yield of $P$. sajor-caju was comparatively low (range 47-78.4\%). The average number of sporophore flushings ranged between 5 and 6 times. Among the species of oyster mushroom, $P$. columbinus and $P$. ostreatus are superior to $P$. sajor-caju are consistent with previous reports elsewhere. The evaluation of $P$. columbinus alone on different bagging systemscontaining partially pasteurized office papers as a growing substrate revealed that polyethylene bags resulted in $109.4 \%$ biological efficiency in contrast to pottery $(86 \%)$, plastic trays $(72 \%)$ or polyester net $(56 \%)$. Such study revealed that an opportunity for commercial implication of oyster mushroom especially P. columbinus for utilization of different feasible and cheap recyclable residues [21].

The yield performances and nutritional contents of three oyster mushroom species (Pleurotus eryngii(Dc. Ex Fr.) quel), Pleurotus ostreatus (Jacq.: Fr.) Kumm.) and Pleurotus sajor-caju (Fr.) Singer) cultivated on wheat stalk was studied [26]. The total fresh mushroom yields obtained with $100 \mathrm{~g}$ material $(70 \%$ mixture) after the three harvests and the total harvest time were calculated. P.sajor-caju gave the highest yield as $20.2 \mathrm{~g}$. The yield of $P$. ostreatus was $17.9 \mathrm{~g}$ and the lowest yield was $P$. eryngii, $4.5 \mathrm{~g}$. Total harvest time of mushrooms were determined. As the $P$. sajor-caju was harvested in 67.46 days, $P$. ostreatus in 82.64 days and $P$. eryngiiin 85.27 days. The biochemical composition analysis the fruiting bodies of mushrooms were collected after the first productive flow with energy, protein, fat, carbohydrate, dietary fibre, moisture, ash (g in $100 \mathrm{~g}$ dried matter) and amino acids ( $\mathrm{mg}$ in $1 \mathrm{~g}$ dried matter) of mushrooms were analyzed significantly.

The cultivation of Oyster mushroom (Pleurotus flabellatus) on seven different substrates such as Mango, Jackfruit, Coconut, Jam, Kadom, Mahogony, Shiris sawdust with wheat bran and $\mathrm{CaCO}_{3}$ were evaluated to find their growth and yield of mushroom. The maximum biological yield per packet was obtained with Mango sawdust 
(150 gm) followed by Mahogony (148 gm), Shiris (146 gm), Kadom (136 gm), Jam (114 gm), Jackfruit (97 gm) and Coconut sawdust $(83 \mathrm{gm})$. The lowest yield was observed in Coconut sawdust (83 gm). However, highest return was obtained with Mango sawdust (Tk 24.86) while the lowest with Jackfruit sawdust (Tk11.68). According to this study Mango sawdust and Shiris sawdust were cost benefit and promising substrates for the growing of Oyster mushroom (Pleurotus flabellatus) [25].

An evaluation study [27] reported that various substrates and supplements for biological efficiency of Pleurotus sajor-caju and Pleurotus ostreatus. The effects of different substrates namely wheat straw(Triticum aestivum), maize stover (Zea mays L), thatch grass (Hyparrhenia filipendula) and oil/protein rich supplements (maize bran, cottonseed hull (Gossypium hirsutum) on biological efficiency of two oyster mushroom species (Pleurotus sajor-caju and P. ostreatus) was determined. Wheat straw had superior performance over maize stover and thatch grass when cultivating $P$. sajor-caju.

According to the research on [22] the high fiber media as the most efficient substrate for the Pleurotus florida culture. They used wheat straw, barley straw, maize stem residue, and lawn residue as substrates coupled with wheat bran, rice bran and soybean powder as complements for the growth of $P$. florida. Wheat and barley straws which contained a high fiber and $\mathrm{C} / \mathrm{N}$ ratio had the best growth period, fruiting body weight, yield, and biological efficiency which achieved by implementation of composts in which high fiber substrates and complements were combined.

The cultivation of oyster mushroom Pleurotus ostreatus on date-palm leaves mixed with other agro-wastes in Saudi Arabia [28] has been studied. It was reported that four agricultural wastes were mixed with date palm leaves at different ratios, with two supplements and three spawn rates used and showed significant result which concluded that wheat straw mixed with date palm at ratio of 25 (date palm): 75 (agro-waste) showed the best results in most of the parameters (measured with $35 \mathrm{~d}$ for pin appearance time, 15 fruiting bodies/bag, 250\% biological efficiency, and $120 \mathrm{~g}$ total yield/bag). Corn meal was superior over wheat bran as a supplement in all treatments (with higher number of fruiting bodies (14), yield (120 g), and biological efficiency (245\%)). Parameter values increased with the increase of the spawn rate of $P$. ostreatus. Treatments with date palm leave wastes contained higher carbohydrates and fibers. No significant differences were found among the fruiting bodies produced on the different agro wastes studied for the different proximate analyzed.

The screening study on [29] the suitable grains substrates for spawn development, growth and yield of Pleurotus eous was studied. According to them the spawn development and yield of $P$. eous depended upon the cereal grains spawns in which Sorghum(7.33 days), paddy grain (8.66 days) and maize grains (9 days) took significantly less time for spawn development and maximum yield was recorded on maize grain $(560.03 \mathrm{~g})$ with BE (83.96 \%) compared to other grains. A report [30] showed that growth and yield performance of the Pleurotus ostreatus on different substrates like cotton seed, paper waste, wheat straw, and sawdust) were tested for their efficacy in oyster mushroom production. This study revealed that oyster mushroom can grow on cotton seed, paper waste, sawdust and wheat straw, with varying growth performances. The highest biological and economic yield, as well as the highest percentage of biological efficiency of oyster mushroom was obtained from cotton seed, while the least was from sawdust.

The mushrooms are a promising food which might overcome protein-energy malnutrition problem in world [31]. In which the essential nutrients such as protein, fiber, mineral, carbohydrates and fat content make them ideal vegetable for diabetic, cancer and heart patients. Those nutrient contents made mushroom as a low energy, healthy foodstuff and they may be also used as protein supplementary. Protein is an important nutritional component and protein deficiency is the world's most serious human nutritional problem, especially in third world countries like Bangladesh.

In the secondary study harvested oyster mushrooms were analyzed for essential nutrient components which was tabulated (Fig: 1). The moisture content was significantly higher $\left(88.93^{\mathrm{b}} \pm 2.470 ; 87.80^{\mathrm{b}} \pm 1.801 \& 87.66^{\mathrm{b}} \pm\right.$ $1.763 \%$ ) in mushrooms derived from news paper, coir and ground nut shell waste substrate when compared to paddy straw substrate $\left(74.20^{\mathrm{a}} \pm 4.582 \%\right.$ )(Table: 2 \& Fig: 2 ). The protein content was maximum as $51.93^{\mathrm{b}_{ \pm}}$ $3.066 \%$ in news paper substrate sample and it was minimum in other substrates $\left(43.06^{\mathrm{ab}} \pm 6.025 \%\right.$ in ground nut shell coat; $42.07 \mathrm{ab}_{ \pm} 1.508 \%$ in paddy straw substrate $\& 37.56^{\mathrm{a}} \pm 4.215 \%$ in coir substrate) sample(Table $: 4 \&$ Fig : 4). The significantly least content of fats, lipid and carbohydrates $\left(0.233^{\mathrm{a}} \pm 0.177 \% ; 0.296^{\mathrm{a}} \pm 0.025 \& 40.79^{\mathrm{a}}\right.$ $\pm 1.405 \%$ ) was measured in both mushrooms derived from news paper substrate (Table:5 \& 6) and ( Fig: 5 \& 6 ) when compared to other substrates $\left(1.000^{\mathrm{c}} \pm 0.100 ; 0.433^{\mathrm{b}} \pm 0.020 ; 67.56^{\mathrm{c}} \pm 5.277 \%\right.$ in Coir substrate, 
$0.433^{\mathrm{bc}} \pm 0.058 ; 0.366^{\mathrm{ab}} \pm 0.040 ; 57.92^{\mathrm{c}} \pm 2.237 \%$ in Ground nut shell substrate and $0.266^{\mathrm{ab}} \pm 0.057 ; 0.323^{\mathrm{a}} \pm 0.035$ $47.77^{\mathrm{a}} \pm 2.797 \%$ in paddy straw substrate). Among these substrates the new paper wastes were suitable one for Pleurotus mushroom cultivation under commercial cultivation process when compared to other substrates. Such nutrient analysis determined the food value of edible mushrooms which are rich of proteins and suggested that they are good dietary food for diabetes patients because of low content of carbohydrates and fats in such mushrooms.

\section{Mushroom growth}

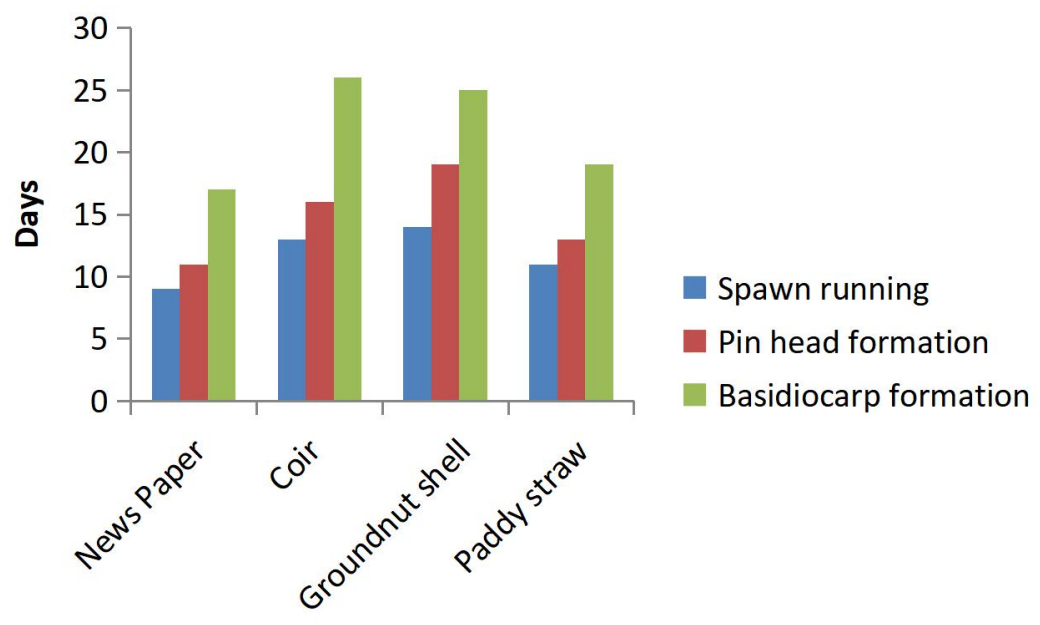

Substrate

Fig: 1 Oyster mushroom growth chart for different substrates

Table: 1 Growth period of oyster mushroom for different biodegradable substrate

\begin{tabular}{ccccc}
\hline \multirow{2}{*}{ Sl. No } & Biodegradable substrate & \multicolumn{3}{c}{ Number of days mushroom bag Incubation } \\
& & Spawn running & Pin head formation & Basidiocarp formation \\
\hline 1 & News paper & 9 & 11 & 17 \\
2 & Coir & 13 & 16 & 26 \\
3 & Ground nut shell & 14 & 19 & 25 \\
4 & Paddy straw & 11 & 13 & 19 \\
\hline
\end{tabular}

\section{Moisture content (\%)}

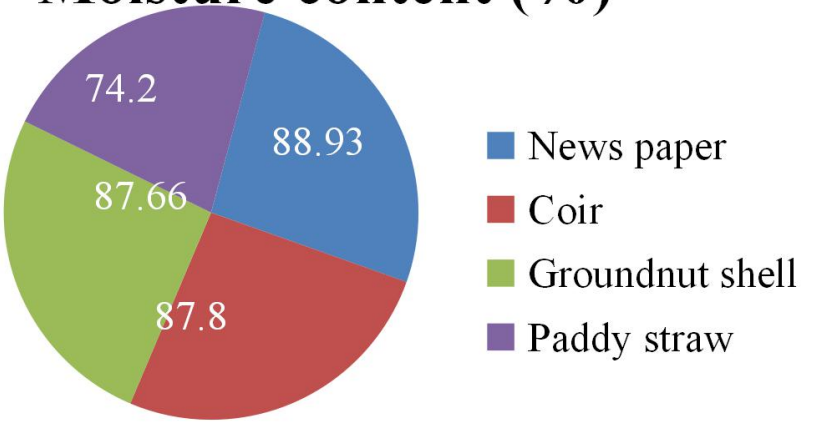

Fig : 2 Effect of biodegradable substrates on the moisture content (\%) of oyster mushroom 
Table: 2 Effect of biodegradable substrates on the moisture content (\%) of oyster mushroom

\begin{tabular}{ccc}
\hline & & Moisture content (\%) \\
Sl. No & Biodegradable substrate & \% \\
\hline 1 & News paper & $88.93^{\mathrm{b}} \pm 2.470$ \\
2 & Coir & $87.80^{\mathrm{b}} \pm 1.801$ \\
3 & Ground nut Shell & $87.66^{\mathrm{b}} \pm 1.763$ \\
4 & Paddy straw & $74.20^{\mathrm{a}} \pm 4.582$ \\
\hline
\end{tabular}

Values are mean of three replicates $\pm \mathrm{SD}$; The mean difference is significant at the 0.05

\section{Ash content (\%)}

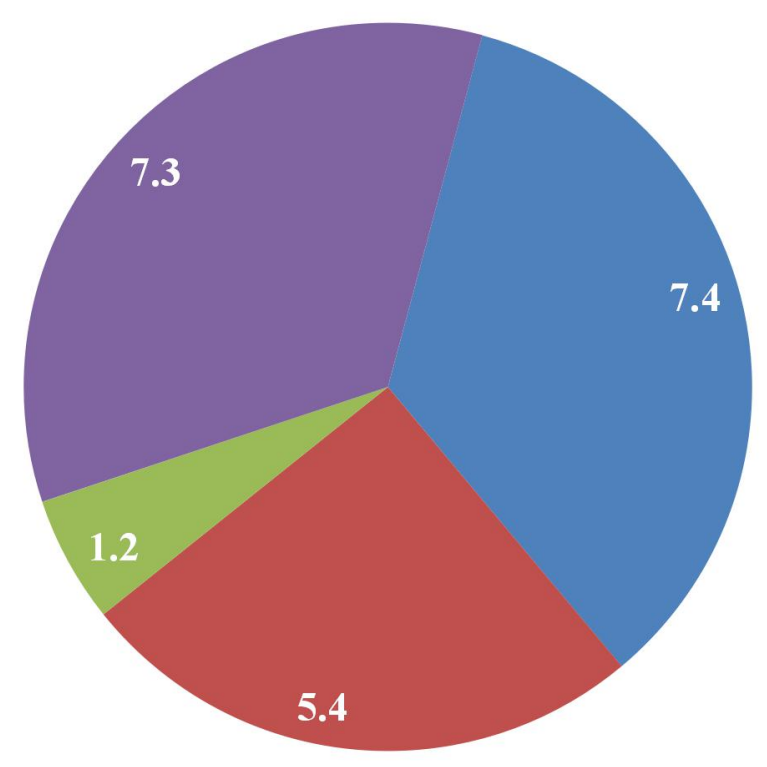

News paper

Coir

Groundnut shell

Paddy straw

Fig :3 Effect of biodegradable substrates on the ash content (\%) of oyster mushroom

Table: 3 Effect of biodegradable substrates on the ash content $(\%)$ of oyster mushroom

\begin{tabular}{ccc}
\hline & \multicolumn{2}{c}{ Ash content (\%) } \\
S.No & Biodegradable substrate & $\%$ \\
\hline 1 & News paper & $7.433^{\mathrm{c}} \pm 0.351$ \\
2 & Coir & $5.666^{\mathrm{b}} \pm 0.568$ \\
3 & Ground nut Shell & $1.166^{\mathrm{a}} \pm 0.208$ \\
4 & Paddy straw & $7.266^{\mathrm{c}} \pm 0.152$ \\
\hline
\end{tabular}

Values are mean of three replicates $\pm \mathrm{SD}$; The mean difference is significant at the 0.05 


\section{Protein content (\%)}

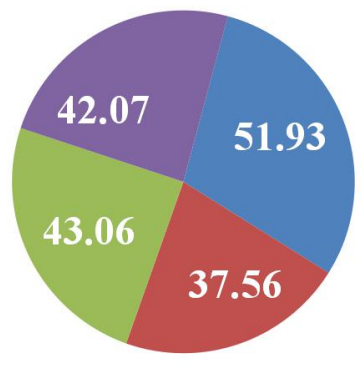

News paper

Coir

Groundnut shell

Paddy straw

Fig :4 Effect of biodegradable substrates on the protein content (\%) of oyster mushroom

Table : 4 Effect of biodegradable substrates on the protein content $(\%)$ of oyster mushroom

\begin{tabular}{ccc}
\hline & \multicolumn{2}{c}{ Protein content (\%) } \\
S.No & Biodegradable substrate & $\%$ \\
\hline 1 & News paper & $51.93^{\mathrm{b}} \pm 3.066$ \\
2 & Coir & $37.56^{\mathrm{a}} \pm 4.215$ \\
3 & Ground nut Shell & $43.06^{\mathrm{ab}} \pm 6.025$ \\
4 & Paddy straw & $42.07^{\mathrm{ab}} \pm 1.508$ \\
\hline
\end{tabular}

Values are mean of three replicates $\pm \mathrm{SD}$; The mean difference is significant at the 0.05

\section{Fat content (\%)}

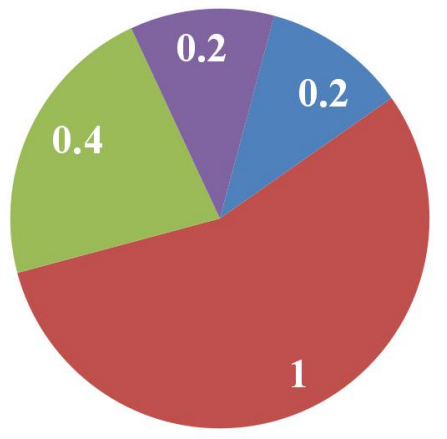

News paper

Coir

Groundnut shell

Paddy straw

Fig :5 Effect of biodegradable substrates on the fat content (\%) of oyster mushroom

Table : 5 Effect of biodegradable substrates on the fat content (\%) of oyster mushroom

\begin{tabular}{|c|c|c|}
\hline \multicolumn{3}{|c|}{ Fat content $(\%)$} \\
\hline S.No & Biodegradable substrate & $\%$ \\
\hline 1 & News paper & $0.233^{a} \pm 0.177$ \\
\hline 2 & Coir & $1.000^{c} \pm 0.100$ \\
\hline 3 & Ground nut Shell & $0.433^{b c} \pm 0.058$ \\
\hline 4 & Paddy straw & $0.266^{\mathrm{ab}} \pm 0.057$ \\
\hline
\end{tabular}

Values are mean of three replicates \pm SD; The mean difference is significant at the 0.05 


\section{Lipid content $(\%)$}

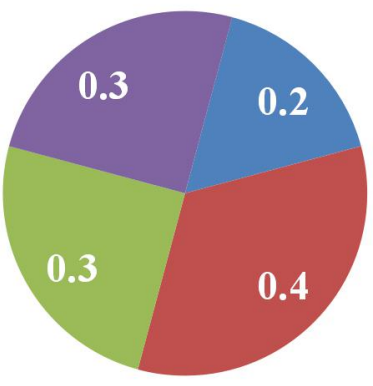

News paper

Coir

Groundnut shell

Paddy straw

Fig :6 Effect of biodegradable substrates on the lipid content (\%) of oyster mushroom

Table : 6 Effect of biodegradable substrates on the lipid content (\%) of oyster mushroom

\begin{tabular}{ccc}
\hline & & Lipid content (\%) \\
\hline S.No & Substrate & \% \\
\hline 1 & News paper & $0.296^{\mathrm{a}} \pm 0.025$ \\
2 & Coir & $0.433^{\mathrm{b}} \pm 0.020$ \\
3 & Ground nut Shell & $0.366^{\mathrm{ab}} \pm 0.040$ \\
4 & Paddy straw & $0.323^{\mathrm{a}} \pm 0.035$ \\
\hline
\end{tabular}

Values are mean of three replicates $\pm \mathrm{SD}$; The mean difference is significant at the 0.05

\section{Carbohydrate content (\%)}

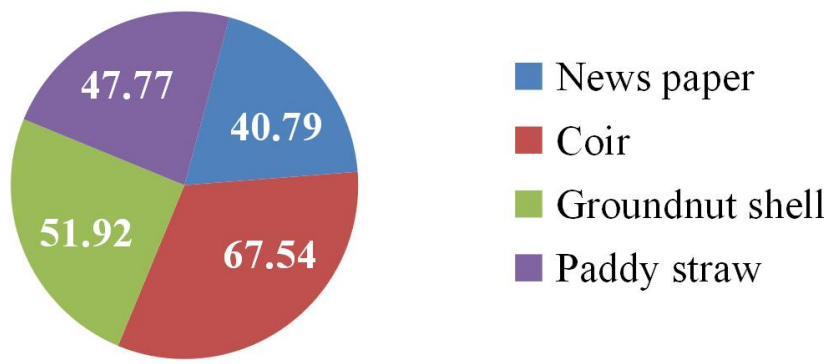

Fig : 7 Effect of biodegradable substrates on the carbohydrate content (\%) of oyster mushroom

Table : 7 Effect of biodegradable substrates on the carbohydrate (\%) content of oyster mushroom

\begin{tabular}{ccc}
\hline & \multicolumn{2}{c}{ Carbohydrate content (\%) } \\
S.No & Biodegradable substrate & \% \\
\hline 1 & News paper & $40.79^{\mathrm{a}} \pm 1.405$ \\
2 & Coir & $67.56^{\mathrm{c}} \pm 5.277$ \\
3 & Ground nut Shell & $57.92^{\mathrm{c}} \pm 2.237$ \\
4 & Paddy straw & $47.77^{\mathrm{a}} \pm 2.797$ \\
\hline
\end{tabular}

Values are mean of three replicates $\pm \mathrm{SD}$; The mean difference is significant at the 0.05 
The fruiting bodies of young mushrooms are soft and brittle; therefore contain higher moisture than fully matured ones which are tough and almost leathery as they lost some of water content [32]. In certain study, most fresh mushrooms contained about $90 \%$ moisture and $10 \%$ of dry matter and dry mushrooms contained about $90 \%$ of dry matter and $10 \%$ of moisture [2].

The testing of [33] the mushrooms (Pleurotus roseus, Pleurotus ostreatus, Pleurotus sajor caju, Termitomyces microcarpus, Termitomyces heimii, Auricularia auricular, adversely affected the regeneration and growth pattern of the delicate fungi which requires a specific micro-climate. Consequently, the high nutritional quality and unique flavor of these Volvariella volvacea, Lentinus squarrosulus, Lentinus tuberegium, Grifola frondosa) possess carbohydrate and protein content in rich quantity and with low fat content. The ash and fiber content were less than other foods of plant and animal origin.

The investigation on edible mushroom Pleurotus citrinopileatus growth on paddy straw mixed with Brassica straw, pea pod shell, cauliflower leaves and radish leaves gave fruit bodies with enhanced protein, sugar and amino acid content. Besides, these substrates it also support better yield performance and biological efficiency [34]. Commonly, three vegetable wastes namely pea pod shell, cauliflower leaves and radish leaves were used in the investigation were generated from every households and vegetable markets in large quantities. Such wastes were generally left to rot in situ in many cities of India causing outbreak of many diseases. It pollutes the environment and causes various environmental problems which could be utilized beneficially as resources for mushroom production with improved nutraceutical values.

The cultivation and nutrient analysis [11] of oyster mushroom on different agricultural waste substrate from agro industrial lingo-cellulosic waste and residues was studied. The development of Oyster mushroom (Grey and pink) production methodologies on agricultural waste like Paddy straw and wheat straw gives very high yield as well as the nutritional contain like carbohydrate, protein, ash, calcium, magnesium, crude fibers and lipid were checked. According to the report the moisture contents of grey mushroom on wheat straw was $87.5 \%$ that on paddy straw was $77.5 \%$. Mushrooms on wheat straw was $92 \%$ and in paddy straw was $86.11 \%$. Total carbohydrate content of mushroom in wood scrap was $(68.6 \mathrm{~g} / 100 \mathrm{gm})$ and wheat straw was $(66.7 \mathrm{~g} / 100 \mathrm{gm})$.

The above result and discussion of the present research suggested that the news paper waste were the best biodegradable substrate for the oyster mushroom cultivation for commercial aspects. Apart from the food value of Pleurotus mushrooms such organisms were the good decomposers of our ecosystem. Thus the mushroom cultivation is the commercial technique of solid state fermentation method in biotechnology which had lots of advantages like low grade substrate - ligno cellulosic waste recycling and high productivity using biodegradable lingo cellulosic substrate approximately reducing environmental pollution.

\section{Conclusion}

Human have been eating different food groups such as meat and plant based including fungi. Mushroom fungi are commonly grown in the shady area and propagated through its spores. Even today many people throughout the world consume mushrooms as healthy food, with low calories and fat but high in vegetable proteins, chitin, vitamins and minerals. Mushrooms cultivation fits in very well with sustainable farming and has several advantages. The cultivation of edible fungi is controlled bio-conservation of agro industrial cellulosic waste and residues. The development of mushroom production methodologies on agricultural waste like paddy straw and wheat straw gives very high yield. The present investigation analyzed the growth of Oyster mushroom using different substrates and suggested that newspaper wastes was the best suitable substrate and medium for the Pleurotus mushroom cultivation. These mushrooms are not only produce nutritionally valuable fruiting body which also lead to reduce the unwanted waste dumping and burning. Such mushroom technology was highly applicable in our society to clean the environment eco-friendly.

\section{Acknowledgement}

The authors have expressed their immense thanks to the President, Vice-President,, Secretary, Principal, HOD of the Botany Department, Thiagarajar College, Madurai, Tamil Nadu, India for their encouragement and provided the facilities for the successful completion of the research work. And also they expressed their sincere thanks to their family and friends for the successful work. 


\section{References}

[1] Obodai, M and Vowotor, K.A (2002) Performance of different strains of Pleurotus Food Technol in Africa, 7 (3): 98-100

species under Ghanaian conditions. J of

[2] Chang,S.T.,Lau,W.O., Cho, K.Y (1981)The cultivation and nutritional value of Pleurotus sajor-caju. Euro J of Appl Microbiol, 12 (1):58-62

[3] Oei, P(2003) Mushroom Cultivation. Appropriate Technology for Mushroom Growers, 3rd ed. Backhuys Pub., Leiden, Netherlands, 426

[4] Eger, G., Eden, G., Wissig, E (1976) Pleurotus ostreatus, breeding potential of a new cultivated mushroom. Theor. Appl. Genet, 47:155-163

[5] Yildiz, A and Ertekin, A.S (1996) An experimental study of mycelia development periods of some Pleurotus species. Mush. Res, 5:81-88

[6] Khan, S.M and Chaudhary, I.A(1987) Some studies on oyster mushroom (Pleurotus spp.) on the waste material of corn industry in Pakistan. Mush sci, 12 (2):23-29

[7] Yalinkilic, M.K., Altun, L., Baysal, E and Demirci, Z (1994) Development of mushroom cultivation techniques in Eastern Black Sea Region of Turkey. Project of the Scientific and Technical Research Council of Turkey (TUBITAK), No TOAG-875, 287

[8] Eswaran, A., Ramabadran, R (2000) Studies on some physiological, cultural and post harvest aspects of oyster mushroom Pleurotus eous. Tropical Agri Res, 12:360-374

[9] Bahl, N. (1998) Hand book on mushrooms. Oxford \&IBH Publishing co. Pvt. Ltd.:15-40

[10] Oei, P (2005) Small scale mushroom cultivation. Agrodok 40. CTA Pub., Wageningen, The Netherlands, 86

[11] Randive, S.D (2012) Cultivation and study of growth of oyster mushroom on different agricultural waste substrate and its nutrient analysis. Adv in Appl Sci Res, 3 (4):1938-1949

[12] Naraian, R., Srivastava, J and Garg, S.K (2011) Influence of dairy spent wash (DSW) on different cultivation phases and yield response of two Pleurotus mushrooms. Annals of Microbiol, 61:853-862

[13] Quimio, T. H., Chang, S. T and Royse, D. J (1990) Technical guidelines for mushrooms growing in the Tropic. FAO Plant Production and Protection, 106:152

[14] Zadrazil, F and Kurtzman, J.R (1982) The Biology of Pleurotus cultivation in the tropics.In: Chang, S. T. and Quimio, T. H. (eds.). Tropical Mushrooms, Biological Nature and Cultivation Methods. The Chinese University Press. Hong Kong 493

[15] Raghuramulu, N., Madhavan, N.K and Kalyanasundaram, S (2003) A manual of Laboratory Techniques, pp.56-58. National Institute of Nutrition. Indian Council of Medical Research, Hyderabad, India

[16] AOAC. (1990) Official method analysis. Association of Analytical Chemists. Washington D.C.15th edition,pp:1298

[17] Folch, J., Lees,M and Sloane, G.H (1957) A simple method for the isolation and purification of total lipids from animal tissues. J. Biol. Chem, 226, 497-509

[18] Bradford, M.M (1976) A rapid and sensitive method for the quantitation of microgram quantities of protein utilizing the principle of protein-dye binding. Anal Biochem, 7 (72): 248-54

[19] Soto-Cruz, O and Saucedo-Castaneda, G (1999) Effect of substrate composition on the mycelia growth of Pleurotus ostreatus. An analysis by mixture and response surface methodologies. Process Biochem, 35: (1-2) 127-133

[20] Sánchez, C (2010) Cultivation of Pleurotus ostreatus and other edible mushrooms. Appl. Microbiol. Biotechnol, 85:1321-1337.

[21] Mandeel, Q.A., Al-Laith, A.A and Mohamed, S.A (2005) Cultivation of oyster mushrooms (Pleurotus spp.) on various lingo cellulosic wastes. World J of Microbiol \& Biotechnol, 21:601-607

[22] Jafarpour,M., Jalaliz, A and Eghbalsaied, S (2011) High fiber media as the most efficient substrates for Pleurotus florida culture. Arch. Biol. Sci. Belgrade, 63 (3): 889-895

[23] Oseni, T.O., Dlamini, S.O., Eranshaw, D.M and Michael, T (2012) Effect of Substrate Pre-treatment Methods on Oyster Mushroom (Pleurotus ostreatus) Production. Inter J Agri \&Biol ISSN Print: 1560-8530; ISSN Online: 1814-959611-373/MFA/14-2- 251-255

[24] Oei, P. (1996) Manual on mushroom cultivation: Techniques, species and opportunities for commercial applications in developing countries, 1st Edition. Tool Foundation, Amsterdam, The Netherlands. pp. 49-50

[25] Islam,M.Z., Rahman,M.H and Hafiz, F (2009) Cultivation of oyster mushroom (Pleurotus flabellatus) on different substrates. Int. J. Sustain. Crop Prod, 4(1):45-48

[26] Dundar, A., Acay, H and Yildiz, A (2008) Yield performances and nutritional contents of three oyster mushroom species cultivated on wheat stalk. Afri J of Biotechnol, 7 (19):3497-3501 
[27] Fanadzo, M., Zireva, D.T., Dube, E and Mashingaidze, A.B (2010) Evaluation of various substrates and supplements for biological efficiency of Pleurotus sajor-caju and Pleurotus ostreatus. Afri J of Biotechnol, 9 (19):2756-2761

[28] Alananbeh, K.M and Bouqellah, N.A (2014) Cultivation of oyster mushroom Pleurotus ostreatus on date-palm leaves mixed with other agro-wastes in Saudi Arabia. Saudi J of biol , 21(6): 616-625

[29] Sahu, S.K., Singh, D.P., Patel, R and Awadhiya, D.K (2014) Screening of suitable grains substrates for Spawn development, growth and yield of Pleurotus eous. American Internat J of Res in Formal, Appl \& Natl Sci ,ISSN (Print): 2328-3777, ISSN (Online): 2328-3785, ISSN (CD-ROM): 2328-3793

[30] Girmay, Z., Gorems, W., Birhanu, G and Zewdie, S (2016) Growth and yield performance of Pleurotus ostreatus (Jacq. Fr.) Kumm (oyster mushroom) on different substrates. AMB Expr, 6:87

[31] Pushpa, H and K. B.Purushothama (2010) Biodiversity of mushrooms in and around Bangalore (Karnataka). World Journal of Dairy \& Food Science, 5(2):140-144

[32] Fasidi, I.O and Kadiri, M (1993) Effect of sporophore maturity on chemical composition of Volvariella esculenta (Mass) Singer-Nigerian Mushroom, 37(3): 269-273

[33] Johnsy, G.,Sargunam, S.D., Dinesh, M.G and Kaviyarasan, V (2011) Nutritive value of edible wild mushrooms collected from the Western Ghats of Kanyakumari District. Bot Res Inter, 4:69-74

[34] Mohan, P. S and Vinay kumar, S (2011) Yield performance and nutritional analysis of Pleurotus citrinopileatus on different agro wastes and vegetable wastes. Proceedings of the 7th International Conference on Mushroom biology and Mushroom products(ICMBMP7), 385-392 